\title{
ANALISIS KONTRASTIF PADA FUNGSI BAHASA JEPANG DAN BAHASA INDONESIA
}

\author{
Kartika Nuswantara, Salsabela Putri Aghnadiin
}

\begin{abstract}
Abstrak
Paper ini mencoba menguraikan ungkapan-ungkapan bahasa Jepang yang umum diajarkan pengajar bahasa Jepang pada pembelajar yang berbicara bahasa Indonesia. Teori analisis kontrastif digunakan untuk memperoleh persamaan sekaligus perbedaan antara ungkapan pada bahasa Jepang dan bahasa Indonesia. Sumber acuan data diambil dari buku ajar Marugoto A1 jilid katsudou. Diperoleh 120 data ungkapan, dan diantaranya yaitu, 97 ungkapan yang mirip, 21 ungkapan yang memiliki perbedaan, dan 2 ungkapan yang tidak ada pembandingnya dalam bahasa Indonesia. Dari hasil ini, didapat bahwa perlu perhatian lebih pada ungkapan yang memiliki perbedaan kemiripan, yaitu ungkapan ajakan/undangan dan menanggapi ajakan/undangan, menawarkan, dan bertamu, serta ungkapan yang tidak ada ungkapan pembanding dari Bahasa Indonesia seperti ungkapan "itadakimasu"-"gochisoosama".
\end{abstract}

Kata kunci: Analisis kontrastif, ungkapan, fungsi bahasa, Bahasa Jepang, Bahasa Indonesia.

Bahasa Jepang merupakan bahasa asing yang mulai diajarkan di sekolah maupun perguruan tinggi di Indonesia sebagai bahasa asing pilihan setelah bahasa Inggris. Minat pembelajar untuk mempelajari dan menguasai bahasa ini juga meningkat tajam dari waktu ke waktu. Salah satu hal yang mendorong pembelajar khususnya pembelajar pada usia Sekolah Menengah hingga Perguruan Tinggi adalah dipergunakannya bahasa Jepang sebagai bahasa pengantar pada jenis-jenis film animasi atau beragam game yang sangat populer di kelompok usia diatas. Dalam lingkungan pendidikan, beasiswa untuk belajar di perguruan tinggi di Jepang yang diberikan oleh pemerintah Jepang kepada pelajar atau mahasiswa Indonesia menjadi alasan lain mengapa bahasa ini menjadi sangat digemari untuk dipelajari. Hal ini menjadi sebuah peluang bagi pengajar bahasa Jepang untuk semakin kreatif dalam berinovasi untuk menciptakan proses pembelajaran bahasa Jepang yang tidak hanya menyenangkan tetapi juga efisien.

Salah satu cara yang dapat dilakukan agar proses pembelajaran menjadi menyenangkan adalah dengan cara memilih materi ajar yang menarik secara visual. Materi yang dilengkapi dengan ilustrasi gambar dan warna yang cerah, secara umum jsh Jurnal Sosial Humaniora, Vol 9 No.1, Juni 2016 
dapat menarik perhatian dan akan memancing gairah belajar pembelajar. Sementara itu, dari sisi proses pembelajaran yang efisien, salah satu caranya adalah dengan cara memanfaatkan bahasa ibu sebagai bahasa pembanding. Analisis kontrastif dapat menjadi pendekatan untuk menjaring persamaan dan perbedaan. Kardaleksa (2006) dan Geethakumary (2002) telah memanfaatkan pendekatan ini dan menyepakati bahwa dalam pembelajaran bahasa kedua apabila ditemukan persamaan yang signifikan pada fitur lingustik pada tingkat strukturnya maka tingkat kesulitan dalam mempelajari bahasa kedua pada waktu yang terbatas memiliki tingkat kesulitan yang rendah.

Paper ini mencoba melakukan analisis kontrastif untuk memperoleh persamaan sekaligus perbedaan yang membentang dalam sebuah rangkaian kesatuan ketika ujaran dalam bahasa Jepang dibandingkan dengan ujaran dalam bahasa Indonesia. Hasil penelitian ini diharapkan dapat memberikan kontribusi dalam bentuk saran bagi pengajar bahasa Jepang untuk mengenali sequence atau urutan materi berdasarkan tingkat persamaan dengan bahasa ibu pembelajar.

\section{Fungsi Bahasa}

Kembali pada era emas Pembelajaran Komunikatif (Communicative Language Teaching, CLT, - Richard \& Rodgers, 1986), maka salah satu bagian penting dalam proses pembelajaran adalah diajarkannya bahasa sebagai fungsi komunikasi. Oleh sebab itu bahasa diajarkan sebagai alat komunikasi dan bukan sebagai system struktur gramatika; atau pemakaian bahasa (use) dari pada penggunaan bahasa (usage); dan kunci utama dalam pemakaian bahasa adalah pemakai bahasa tersebut, yang berarti bahwa fungsi bahasa tergantung pada bagaimana bahasa itu dipergunakan oleh pemakainya. Sejak tahun 70an pendekatan ini dikenal dengan Functional Approach seperti yang dijelaskan oleh Finocchiaro dan Brumfit (1983) seperti berikut ini:

"Language was much more appropriately classified in terms of what people wanted to do with the language (functions)... than in terms of the grammatical items as in traditional language teaching model" (p.12) 
Dari penjelasan tersebut diatas maka sebuah bahasa dapat diklasifikasikan berdasarkan bagaimana seorang pemakai bahasa memerlukan bahasa tersebut untuk digunakan pada situasi tertentu, sehingga bukan bagaimana bahasa itu dibentuk seperti halnya yang diajarkan oleh kelompok tradisional yang lebih menekankan pada sistem dalam sebuah bahasa.

Finocchiaro dan Brumfit (1983) juga mencoba membuat daftar fungsi bahasa yang biasa diajarkan dalam pemebelajaran bahasa yang diklasifikasikan menjadi 4 kelompok yaitu a) personal; b) direktif, c) referential, dan d) imajinatif. Masing masing diantaranya meliputi, a) personal dipergunakan, diantaranya, untuk: mengungkapkan perasaan atau pendapat; membuka dan mengakhiri pembicaraan; mengundang termasuk cara menerima/menolak undangan, memperkenalkan diri dan orang lain; menyatakan persetujuan atau penolakan; menginterupsi pembicaraan; menyampaikan pujian; dan menyampaikan rasa terima kasih. Kelompok kedua yaitu direktif dipergunakan untuk: meminta sesuatu, memberikan saran, membujuk, meminta bantuan, dan memberikan instruksi; sedangkan berikutnya adalah fungsi referential yang meliputi: menanyakan arah, meminta definisi, dan melaporkan; memberikan evaluasi. Dan yang terakhir, fungsi imajinatif seperti membuat puisi atau sajak, dan pemecahan masalah atau misteri.

Berdasarkan klasifikasi diatas maka penelitian ini mencoba melihat bagaimana fungsi bahasa dalam bahasa Jepang dipergunakan sebagai alat komunikasi, sehingga pengguna bahasanya memiliki ungkapan-ungkapan yang dapat dipelajarari dan kemudian dipergunakan oleh pembelajar bahasa Jepang.

\section{Analisis Kontrastif}

Analisis Kontrastif secara umum dipergunakan sebagai pendekatan dalam penelitian yang bersifat induktif dengan tujuan untuk mencari elemen yang berbeda dalam sebuah bahasa (Kardaleska, 2006). Secara umum terminology ini dapat diartikan sebagai metode untuk menganalisa struktur dari dua bahasa yang berbeda sehingga dapat diperkirakan tingkat persamaan dan perbedaan diatara keduanya (Geethakumary, 2006). Adapun persamaan dan perbedaan diantara kedua bahasa tersebut, menurut Kardaleska, dapat ditinjau dari unsur fonologi, morfologi, 
leksikologi, sintaksis, atau analisis teks. Yang menjadi penting dari hasil analisis ini adalah hasil analisis akan dapat dimanfaatkan untuk membuat asumsi tentang tingkat kesulitan yang akan dihadapi pembelajar dalam mempelajari sebuah bahasa target tertentu.

Analisis kontrastif memberikan dasar obyektif dan ilmiah untuk mengajar bahasa kedua. Sambil belajar bahasa kedua, jika bahasa ibu pembelajar dan bahasa target kedua memiliki fitur linguistik signifikan serupa di semua tingkatan struktur mereka, tidak akan ada banyak kesulitan dalam mempelajari bahasa baru dalam waktu yang terbatas. Untuk mengetahui struktur secara signifikan serupa pada kedua bahasa langkah pertama untuk diadopsi adalah bahwa kedua bahasa harus dianalisis secara independen. Setelah analisis independen, untuk memilah fitur yang berbeda dari dua bahasa, perbandingan dua bahasa diperlukan. Dari analisis ini sangat mudah untuk membuat bahwa pada tingkat yang berbeda dari struktur dua bahasa ini ada beberapa fitur sangat mirip dan beberapa cukup berbeda.

Menurut asumsi populer dari analisis kontrastif, kesamaan struktural akan menyebabkan fasilitasi dan perbedaan akan menyebabkan gangguan dalam konteks situasi belajar kedua / bahasa asing. Namun ini hanya prediksi dan pemahaman parsial dari masalah dan prospek dari situasi kedua / bahasa asing. Masalah pelajar tidak selalu dibatasi untuk prediksi studi kontrastif. Guru, kompetensi, motivasi dan sikap peserta didik, metode pengajaran dan bahan ajar adalah variabel lain yang dapat berpengaruh secara signifikan terhadap kedua / pengajaran bahasa asing. Namun, tata bahasa kontrastif sangat berguna untuk guru termotivasi dan pembelajar untuk proses yang lebih efektif belajar mengajar.

Penelitian ini merupakan penelitian deskriptif, dimana peneliti hanya memanfaatkan fenomena yang telah ada untuk diteliti sehingga menghasilkan sebuah gambaran tentang fenomena tersebut. Data yang dipakai berupa kalimat atau frasa sehingga data penelitian ini merupakan data kualitatif. Adapun pendekatan yang dipakai adalah kontrastif analisis yang akan membandingkan fungsi bahasa dalam bahasa Jepang dan bahasa Indonesia. Hasil penelitian merupakan rekomendasi yang akan disampaikan kepada para penyusun silabus, materi maupun pengajar bahasa Jepang bagi pembelajar dengan bahasa ibu bahasa Indonesia. 
Sumber data pada penelitian ini adalah dialog atau sampel dialog yang disadur dari buku pembelajaran bahasa Jepang berjudul Marugoto jilid A1 seri katsudou; sedangkan bahasa Indonesia akan memanfatkan data empiris yang diperoleh berdasarkan pengamatan dan pengalaman peneliti, yang kebetulan memiliki latar belakang penutur asli bahasa Indonesia.

\section{Hasil Dan Pembahasan}

Berdasarkan buku Marugoto jilid katsudou A1 sebagai sumber data, disusun sejumlah 120 data ungkapan. Fungsi bahasa dari ungkapan yang diambil adalah sebagai berikut: 1) sapaan, 2) perpisahan, 3) berterima kasih, 4) perkenalan, 5) ketika makan, 6) memberi pujian dan menanggapi pujian, 7) mengajak atau mengundang, 8) menawarkan, 9) minta tolong, 10) meminta perhatian, 11) membeli sesuatu, 12) bertamu, 13) menelepon, 14) memberi selamat, dan 15) meminta maaf. Data-data tersebut diambil baik dalam bentuk kalimat maupun percakapan utuh jika ada. Berdasarkan pengelompokan Cross-language similarity (Ringbom, H. (2005), diperoleh 97 data pada kategori hubungan antar kedua bahasa 'mirip' (similar relation), 21 data pada 'berbeda' (contrast relation), dan 2 pada 'sama sekali tidak' (zero relation).

Tabel 4.1 Ungkapan dalam Bahasa Jepang dan Bahasa Indonesia

\begin{tabular}{|c|c|c|c|c|}
\hline $\begin{array}{l}\text { No. } \\
\text { Data }\end{array}$ & Fungsi & $\begin{array}{c}\text { Ungkapan } \\
\text { (bahasa Jepang) }\end{array}$ & $\mathrm{Bab} / \mathrm{hal}$ & $\begin{array}{c}\text { Ungkapan } \\
\text { (bahasa Indonesia) }\end{array}$ \\
\hline 1 & \multirow{3}{*}{ Sapaan } & $\begin{array}{l}\text { (A) おはようございます。 } \\
\text { Ohayoo gozaimasu } \\
\text { (B) Ohayoo gozaimasu }\end{array}$ & $\mathrm{L} 1 / 22$ & $\begin{array}{l}\text { (A) Selamat pagi } \\
\text { (B) Selamat pagi }\end{array}$ \\
\hline 2 & & $\begin{array}{l}\text { (A) こんにちは。 } \\
\text { Konnichiwa. } \\
\text { (B) Konnichiwa. }\end{array}$ & $\mathrm{L} 1 / 22$ & $\begin{array}{l}\text { (A) Selamat siang } \\
\text { (B) Selamat siang }\end{array}$ \\
\hline 3 & & $\begin{array}{l}\text { (A) こんばんは。 } \\
\text { Konbanwa. } \\
\text { (B) Konbanwa }\end{array}$ & $\mathrm{L} 1 / 22$ & $\begin{array}{l}\text { (A) Selamat malam } \\
\text { (B) Selamat malam }\end{array}$ \\
\hline 4 & \multirow{2}{*}{ Perpisahan } & $\begin{array}{l}\text { (A)さようなら。 } \\
\text { Sayoonara. }\end{array}$ & $\mathrm{L} 1 / 22$ & (A) Selamat tinggal \\
\hline 5 & & $\begin{array}{c}\text { (B) じゃ、また。 } \\
\text { Jaa, mata. }\end{array}$ & & (B) Sampai ketemu lagi \\
\hline
\end{tabular}




\begin{tabular}{|c|c|c|c|c|}
\hline 6 & & $\begin{array}{l}\text { (A) お先にしつれいします。 } \\
\text { Osaki ni shitsureishimasu }\end{array}$ & $\mathrm{L} 1 / 22$ & (A) Saya pulang duluan, ya. \\
\hline 7 & & $\begin{array}{l}\text { (B) お疲れさまでした。 } \\
\text { Otsukaresama deshita. }\end{array}$ & & (B) Terima kasih atas ........... \\
\hline 8 & \multirow{3}{*}{$\begin{array}{l}\text { Berterima } \\
\text { kasih }\end{array}$} & \multirow{3}{*}{$\begin{array}{l}\text { (A) (1) ありがとうございます。 } \\
\text { Arigatou gozaimasu. } \\
\text { (2) すみません。 } \\
\text { Sumimasen. } \\
\text { (B) いいえ } \\
\text { Iie }\end{array}$} & \multirow[t]{3}{*}{$\mathrm{L} 1 / 23$} & \multirow{3}{*}{$\begin{array}{l}\text { (A) (1) Terima kasih. } \\
\text { (2) Maaf (terima kasih) } \\
\text { (B) Tidak. }\end{array}$} \\
\hline 9 & & & & \\
\hline 10 & & & & \\
\hline 11 & \multirow{10}{*}{ Perkenalan } & $\begin{array}{l}\text { はじめまして。山田です。 } \\
\text { Hajimemashite. Yamada desu. }\end{array}$ & $\mathrm{L} 3 / 32$ & Perkenalkan. Saya Yamada. \\
\hline 12 & & \multirow{3}{*}{$\begin{array}{l}\text { (A) おなまえは? } \\
\text { O-namae wa? } \\
\text { (B) ワンです。 } \\
\text { Wan desu. } \\
\text { (B) どうぞよろしく。 } \\
\text { Doozo yoroshiku. } \\
\text { (A) どうぞよろしく。 } \\
\text { Doozo yoroshiku. }\end{array}$} & \multirow[t]{3}{*}{$\mathrm{L} 3 / 32$} & \multirow{3}{*}{$\begin{array}{l}\text { (A) Namanya siapa? } \\
\text { (B) Saya Wan. } \\
\text { (B) Senang berkenalan dengan } \\
\text { anda } \\
\text { (A) Senang berkenalan dengan } \\
\text { anda }\end{array}$} \\
\hline 13 & & & & \\
\hline 14 & & & & \\
\hline 15 & & \multirow{4}{*}{$\begin{array}{l}\text { (A) はじめまして。 キムです。 } \\
\text { Hajimemashite. Kimu desu. } \\
\text { どうぞよろしく。 } \\
\text { Doozo yoroshiku. } \\
\text { (B) はじめまして。野田です。 } \\
\text { Hajimemashite. Noda desu. } \\
\text { どうぞよろしく。 } \\
\text { Doozo yoroshiku. }\end{array}$} & \multirow[t]{4}{*}{$\mathrm{L} 3 / 35$} & (A) Perkenalkan. Saya Kimu. \\
\hline 16 & & & & Senang berkenalan dengan anda. \\
\hline 17 & & & & (B) Perkenalkan. Saya Noda. \\
\hline 18 & & & & Senang berkenalan juga. \\
\hline 19 & & \multirow{2}{*}{$\begin{array}{l}\text { はじめまして。佐藤 申します。 } \\
\text { Hajimemashite. Satoo to mooshimasu. } \\
\text { どうぞよろしくお願いします。 } \\
\text { Doozo yoroshiku onegaishimasu }\end{array}$} & \multirow[t]{2}{*}{$\mathrm{L} 3 / 35$} & Nama saya ___ (formal) \\
\hline 20 & & & & $\begin{array}{l}\text { Senang berkenalan dengan anda } \\
\text { (formal) }\end{array}$ \\
\hline 21 & \multirow{2}{*}{ Ketika makan } & $\begin{array}{l}\text { いただきます。 } \\
\text { Itadakimasu }\end{array}$ & $\mathrm{L} 5 / 44$ & 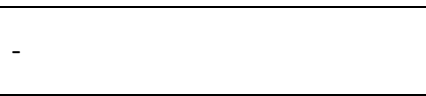 \\
\hline 22 & & $\begin{array}{l}\text { ごちそうさま。 } \\
\text { Gochisoosama }\end{array}$ & $\mathrm{L} 5 / 44$ & - \\
\hline 23 & \multirow{7}{*}{$\begin{array}{l}\text { Memberi } \\
\text { pujian/ } \\
\text { membalas } \\
\text { pujian }\end{array}$} & \multirow{7}{*}{$\begin{array}{l}\text { (A) この人はだれですか。 } \\
\text { Kono hito wa dare desu ka? } \\
\text { (B) わたしのあにです。 } \\
\text { Watashi no ani desu. } \\
\text { (A) へえ,かっこいいですね。 } \\
\text { おいくつですか。 } \\
\text { Hee, kakkoii desu ne. Oikutsu desu ka? } \\
\text { (B) 33さいです。 } \\
\text { 33-sai desu. } \\
\text { (A) どこにすんでいますか。 } \\
\text { Doko ni sundeimasu ka? } \\
\text { (B) 東京にすんでいます。 } \\
\text { かいしやいんです。 } \\
\text { Tookyoo ni sundeimasu. Kaishain desu. } \\
\text { (A) そうですか。 }\end{array}$} & \multirow[t]{7}{*}{$\mathrm{L} 4 / 128$} & (A) Orang ini siapa? \\
\hline 24 & & & & (B) Kakakku. \\
\hline 25 & & & & $\begin{array}{l}\text { (A) Wah, ganteng ya. Umurnya } \\
\text { berapa? }\end{array}$ \\
\hline 26 & & & & (B) 33 tahun. \\
\hline 27 & & & & (A) Tinggalnya di mana? \\
\hline 28 & & & & $\begin{array}{l}\text { (B) Tinggal di Tokyo. } \\
\text { Dia pegawai kantor. }\end{array}$ \\
\hline 29 & & & & (A) Ooh. \\
\hline
\end{tabular}




\begin{tabular}{|c|c|c|c|c|}
\hline & & Soo desu ka. & & \\
\hline 30 & & $\begin{array}{l}\text { (A)この子はだれですか。 } \\
\text { Kono ko wa dare desu ka? }\end{array}$ & $\mathrm{L} 4 / 128$ & \\
\hline 31 & & $\begin{array}{l}\text { (B) ああ、あにのこどもです。 } \\
\text { Aa, ani no kodomo desu. }\end{array}$ & & (B) Oh, anak kakakku. \\
\hline 32 & & $\begin{array}{l}\text { (A) かわいいですね。おいくつですか。 } \\
\text { Kawaii desu ne. Oikutsu desu ka? }\end{array}$ & & (A) Lucu, ya. Umurnya berapa? \\
\hline 33 & & $\begin{array}{l}\text { (B) 6さいです。 } \\
\text { 6-sai desu. }\end{array}$ & & (B) 6 tahun. \\
\hline 34 & & $\begin{array}{l}\text { (A)6さい。そうですか。 } \\
\text { 6-sai. Soo desu ka. }\end{array}$ & & (A) Oh, 6 tahun. \\
\hline 35 & & $\begin{array}{l}\text { (A) このひとはだれですか。 } \\
\text { Kono hito wa dare desu ka? }\end{array}$ & $\mathrm{L} 4 / 128$ & (A) Orang ini siapa? \\
\hline 36 & & $\begin{array}{l}\text { (B) ちちです。 } \\
\text { Chichi desu. }\end{array}$ & & (B) Ayahku. \\
\hline 37 & & $\begin{array}{l}\text { (A) え、おとうさんは65さいです。 } \\
\text { E, otoosan. Oikutsu desu ka? }\end{array}$ & & (A) Eh, ayah? Berapa usianya? \\
\hline 38 & & $\begin{array}{l}\text { (B) ええっと、ちちは6 5さいです。 } \\
\text { Eetto, chichi wa 65-sai desu. }\end{array}$ & & (B) Hmm, umur beliau 65 tahun. \\
\hline 39 & & $\begin{array}{c}\text { (A) } 6 \text { 5さい。おわかいですね。 } \\
\text { 65-sai. Owakai desu ne. }\end{array}$ & & (A) 65 tahun? Masih muda ya. \\
\hline 40 & & $\begin{array}{l}\text { (B)そうですか。ひとりでほっかいどうにすんでい } \\
\text { ます。 } \\
\text { Soo desu ka. Hitori de Hokkaidoo ni } \\
\text { sundeimasu. }\end{array}$ & & $\begin{array}{l}\text { (B) Oh, begitu? Beliau tinggal di } \\
\text { Hokkaido sendirian. }\end{array}$ \\
\hline 41 & & $\begin{array}{l}\text { (A) このひと、だれですか ?きれいですね。 } \\
\text { Kono hito, dare desu ka? Kirei desu ne. }\end{array}$ & $\mathrm{L} 4 / 128$ & (A) Orang ini, siapa? Cantik ya. \\
\hline 42 & & $\begin{array}{l}\text { (B) いもうとです。22さいです。 } \\
\text { Imooto desu. 22-sai desu. }\end{array}$ & & (B) Adikku. Umurnya 22 tahun. \\
\hline 43 & & $\begin{array}{l}\text { (A)ヘえ、どこにすんでいますか? } \\
\text { Hee, doko ni sundeimasu ka? }\end{array}$ & & $\begin{array}{l}\text { (A) Hee, (sekarang) tinggal di } \\
\text { mana? }\end{array}$ \\
\hline 44 & & $\begin{array}{l}\text { (B) フランスのパリです。 } \\
\text { いもうとは学生です。 } \\
\text { Furansu no Pari desu. Imooto wa gakusei } \\
\text { desu. }\end{array}$ & & $\begin{array}{l}\text { (B) Di Perancis, di kota Paris. } \\
\text { Adikku mahasiswa. }\end{array}$ \\
\hline 45 & & $\begin{array}{l}\text { (A)ヘえ、そうですか。 } \\
\text { Hee, soo desu ka. }\end{array}$ & & (A) Ooh. \\
\hline 46 & & $\begin{array}{l}\text { (A) いいへやですね。 } \\
\text { Ii heya desu ne. }\end{array}$ & $\mathrm{L} 8 / 57$ & (A) Ruangannya bagus ya. \\
\hline 47 & & $\begin{array}{l}\text { (B) どうもありがとう。 } \\
\text { Doomo arigatoo. }\end{array}$ & & (B) Terima kasih. \\
\hline 48 & & $\begin{array}{l}\text { (A) これ、なんですか。 } \\
\text { Kore, nan desu ka? }\end{array}$ & $\mathrm{L} 8 / 57$ & (A) Ini apa? \\
\hline 49 & & $\begin{array}{l}\text { (B) かんこくのにんぎょうです。 } \\
\text { Kankoku no ningyoo desu. }\end{array}$ & & (B) Boneka Korea. \\
\hline 50 & & $\begin{array}{l}\text { (A) そうですか。きれいですね。 } \\
\text { Soo desu ka. Kiree desu ne. }\end{array}$ & & (A) Ooh. Cantik ya. \\
\hline 51 & & $\begin{array}{l}\text { (A) きょうはどこで食べますか。 } \\
\text { Kyoo wa doko de tabemasu ka? }\end{array}$ & L6/47 & (A) Hari ini mau makan di mana? \\
\hline 52 & $\begin{array}{l}\text { Mengajak/ } \\
\text { mengundang }\end{array}$ & $\begin{array}{l}\text { (B) あのみせで食べましょう。 } \\
\text { Ano mise de tabemashoo. }\end{array}$ & & (B) Ayo makan di warung itu. \\
\hline 53 & & (A) ラーメンですか。 & & (A) Ramen? \\
\hline
\end{tabular}




\begin{tabular}{|c|c|c|c|}
\hline & \multirow{3}{*}{$\begin{array}{l}\text { Raamen desu ka? } \\
\text { (B) はい、あのみせはおいしいですよ。 } \\
\text { Hai, ano mise wa oishii desu yo. } \\
\text { (A) じや、そうしましょう。 } \\
\text { Jaa, soo shimashoo. }\end{array}$} & & \multirow{3}{*}{$\begin{array}{l}\text { (B) Ya, warung itu enak lho. } \\
\text { (A) Kalau begitu, ayo. }\end{array}$} \\
\hline 54 & & & \\
\hline 55 & & & \\
\hline 56 & \multirow{5}{*}{$\begin{array}{l}\text { (A) らいしゅうカーラさんのバースデーパーティ } \\
\text { 一をします。 } \\
\text { いつがいいですか。 } \\
\text { Raishuu Kaara-san no baasudee-paathii o } \\
\text { shimasu. } \\
\text { Itsu ga ii desu ka? } \\
\text { (B) (1) にちようびがいいです。 } \\
\text { Nichiyoobi ga ii desu. } \\
\text { にちようびはだいじょうぶです。 } \\
\text { (2) Nichiyoobi wa daijoobu desu. } \\
\text { (3) いつでもいいです。 } \\
\text { Itsudemo ii desu. } \\
\text { (4) どようびはだめです。 } \\
\text { すみません。 } \\
\text { Doyoobi wa dame desu. Sumimasen. }\end{array}$} & \multirow[t]{5}{*}{$\mathrm{L} 10 / 68$} & \multirow{5}{*}{$\begin{array}{l}\text { (B) (1) Hari minggu saya bisa. } \\
\text { (2) Hari minggu tidak apa- } \\
\text { apa. } \\
\text { (3) Kapan saja saya bisa. } \\
\text { (4) Hari Sabtu saya tidak } \\
\text { bisa. Maaf. }\end{array}$} \\
\hline 57 & & & \\
\hline 58 & & & \\
\hline 59 & & & \\
\hline 60 & & & \\
\hline 61 & \multirow{6}{*}{$\begin{array}{l}\text { (A) もしもし。 } \\
\text { Moshi-moshi. } \\
\text { (B) もしもし、ジョイさんですか。 } \\
\text { キムです。 } \\
\text { Moshi-moshi, Joi-san desu ka? Kimu } \\
\text { desu. } \\
\text { (A) ああ、 キムさん、こんにちは。 } \\
\text { Aa, Kimu-san, konnichiwa. } \\
\text { (B) あのj、らいしゅうカーラさhの } \\
\text { バースデーパーティーをします。 } \\
\text { ジョイさんはいつがいいですか。 } \\
\text { Anou, raishuu Kaara-san no baasudee } \\
\text { paatii o shimasu. Joi-san wa itsu ga ii } \\
\text { desu ka? } \\
\text { (A) にちようびがいいです。 } \\
\text { キムさんは? } \\
\text { Nichiyoobi ga ii desu. Kimu-san wa? } \\
\text { (B) わたしですか。 わたしはいつでもいいです。 } \\
\text { Watashi desu ka? Watashi wa itsudemo ii } \\
\text { desu. }\end{array}$} & \multirow[t]{6}{*}{ L10/134 } & \multirow{3}{*}{$\begin{array}{l}\text { (A) Halo. } \\
\text { (B) Halo, Bu Joy? Saya Kimu. } \\
\text { (A) Oh, Bu Kim. Selamat siang. }\end{array}$} \\
\hline 62 & & & \\
\hline 63 & & & \\
\hline 64 & & & \multirow{3}{*}{$\begin{array}{l}\text { (B) Begini, minggu depan akan } \\
\text { ada pesta ulang tahun Mbak } \\
\text { Carla. Bu Joy kapan bisanya? } \\
\text { (A) Saya hari Minggu bisa. Kalau } \\
\text { Bu Kim? } \\
\text { (B) Saya? Kalau saya kapan saja } \\
\text { bisa. }\end{array}$} \\
\hline 65 & & & \\
\hline 66 & & & \\
\hline 67 & \multirow{4}{*}{$\begin{array}{l}\text { (B) 鈴木さんはいつがいいですか。 } \\
\text { Suzuki-san wa itsu ga ii desu ka? } \\
\text { (A) どようびはだめです。 } \\
\text { いもうとがわたしのいえに来ます。すみません } \\
\text { 。 } \\
\text { Doyoobi wa dame desu. Imooto ga } \\
\text { watashi no ie ni kimasu. Sumimasen. } \\
\text { (B) にちようびは? } \\
\text { Nichiyoobi wa? } \\
\text { (A) にちようびはだいじょうぶです。 } \\
\text { Nichiyoobi wa daijoobu desu. }\end{array}$} & \multirow[t]{4}{*}{ L10/134 } & \multirow{2}{*}{$\begin{array}{l}\text { (B) Bu Suzuki bisa kapan? } \\
\text { (A) Saya hari Sabtu tidak bisa. } \\
\text { Adik saya datang ke rumah. } \\
\text { Maaf, ya. }\end{array}$} \\
\hline 68 & & & \\
\hline 69 & & & \multirow{2}{*}{$\begin{array}{l}\text { (B) Kalau hari Minggu? } \\
\text { (A) Minggu saya tidak apa-apa. }\end{array}$} \\
\hline 70 & & & \\
\hline 71 & $\begin{array}{l}\text { (B) シンさんはいつがいいですか。 } \\
\text { Shin-san wa itsu ga ii desu ka? }\end{array}$ & L10/134 & (B) Pak Shin bisa kapan? \\
\hline
\end{tabular}




\begin{tabular}{|c|c|c|c|c|}
\hline 72 & & $\begin{array}{l}\text { (A) どようびはだめです。しごとです。 } \\
\text { にちようびがいいです。キムさんは? } \\
\text { Doyoobi wa dame desu. Shigoto desu. } \\
\text { Nichiyoobi ga ii desu. Kimu-san wa? }\end{array}$ & & $\begin{array}{l}\text { (A) Saya hari Sabtu tidak bisa. } \\
\text { Saya kerja. Saya hari Minggu } \\
\text { bisa. Kalau Bu Kim? }\end{array}$ \\
\hline 73 & & $\begin{array}{l}\text { (B) わたしはいつでもいいです。 } \\
\text { Watashi wa itsudemo ii desu. }\end{array}$ & & (B) Saya kapan saja bisa. \\
\hline 74 & & $\begin{array}{l}\text { (A) らいしゅうまつりがありますよ。 } \\
\text { Raishuu matsuri ga arimasu yo. }\end{array}$ & $\mathrm{L} 12 / 81$ & $\begin{array}{l}\text { (A) Minggu depan ada perayaan, } \\
\text { lho. }\end{array}$ \\
\hline 75 & & $\begin{array}{l}\text { (B) いつですか。 } \\
\text { Itsu desu ka? }\end{array}$ & & (B) Kapan? \\
\hline 76 & & $\begin{array}{l}\text { (A)7 がつ2 } 5 \text { にちです。 } \\
\text { Shichi-gatsu nijuu-go-nichi desu. }\end{array}$ & & (A) Tanggal 25 Juli. \\
\hline 77 & & $\begin{array}{l}\text { いっしょにみにいきませんか。 } \\
\text { Isshoni mi ni ikimasen ka? }\end{array}$ & & Mau pergi bareng? \\
\hline 78 & & $\begin{array}{c}\text { (B) (1) いいですね。いきましょう。 } \\
\text { Ii desu ne. Ikimashoo. }\end{array}$ & & (B) (1) Wah, boleh juga. Ayo. \\
\hline 79 & & $\begin{array}{c}\text { (2) はい、たぶんだいじょうぶです。 } \\
\text { Hai, tabun daijoobu desu. }\end{array}$ & & $\begin{array}{l}\text { (2)Ya, sepertinya tidak apa- } \\
\text { apa. }\end{array}$ \\
\hline 80 & & $\begin{array}{l}\text { (3) } 25 \text { にちはちょっと ... } \\
\text { すみません。 } \\
\text { Nijuu-go-nichi wa chotto... } \\
\text { Sumimasen }\end{array}$ & & $\begin{array}{l}\text { (3) Tanggal } 25 \text { sepertinya } \\
\text { agak sulit. Maaf, ya. }\end{array}$ \\
\hline 81 & & $\begin{array}{l}\text { (4) } 25 \text { にちはだめです。 } \\
\text { すみません。 } \\
\text { Nijuu-go-nichi wa dame desu. } \\
\text { Sumimasen. }\end{array}$ & & $\begin{array}{l}\text { (4) Tanggal } 25 \text { saya tidak } \\
\text { bisa. Maaf, ya. }\end{array}$ \\
\hline 82 & & $\begin{array}{l}\text { (A) (1) ざんねんです。 } \\
\text { Zannen desu. }\end{array}$ & & (A) (1) Sayang sekali. \\
\hline 83 & & $\begin{array}{c}\text { (2) そうですか。じやあ、またこんど。 } \\
\text { Soo desu ka. Jaa, mata kondo. }\end{array}$ & & $\begin{array}{l}\text { (2) Ooh. Kalau begitu, lain } \\
\text { kali ya. }\end{array}$ \\
\hline 84 & \multirow{8}{*}{ Menawarkan } & $\begin{array}{l}\text { (A) コーヒー、のみますか。 } \\
\text { Koohii, nomimasu ka? }\end{array}$ & $\mathrm{L} 5 / 43$ & (A) Mau minum kopi? \\
\hline 85 & & $\begin{array}{l}\text { (B) (1) はい、おねがいます。 } \\
\text { Hai, onegaishimasu }\end{array}$ & & (B) (1) Ya, tolong ya \\
\hline 86 & & $\begin{array}{c}\text { (2) いいえ、けっこうです。 } \\
\text { Iie, kekkoo desu }\end{array}$ & & (2) Tidak, terima kasih \\
\hline 87 & & $\begin{array}{l}\text { (A) はい、どうぞ。 } \\
\text { Hai, doozo }\end{array}$ & & (A) Ini, silakan \\
\hline 88 & & $\begin{array}{l}\text { (B) すみません。 } \\
\text { Sumimasen }\end{array}$ & & (B) Terima kasih \\
\hline 89 & & $\begin{array}{c}\text { (A) おちや、どうぞ。 } \\
\text { Ocha, doozo }\end{array}$ & $\mathrm{L} 8 / 57$ & (A) Tehnya, silakan \\
\hline 90 & & $\begin{array}{l}\text { (B) いただきます。 } \\
\text { Itadakimasu }\end{array}$ & & (B) Terima kasih \\
\hline 91 & & $\begin{array}{l}\text { (B) おいしいですね。 } \\
\text { Oishii desu ne }\end{array}$ & & \\
\hline 92 & \multirow{3}{*}{ Minta tolong } & \multirow{3}{*}{$\begin{array}{l}\text { きいてください。 } \\
\text { Kiite kudasai. } \\
\text { かいてください。 } \\
\text { Kaite kudasai. } \\
\text { よんでください。 } \\
\text { Yonde kudasai. }\end{array}$} & \multirow[t]{3}{*}{$\mathrm{L} 2 / 26$} & Tolong dengarkan. \\
\hline 93 & & & & Tolong tuliskan. \\
\hline 94 & & & & Tolong bacakan. \\
\hline
\end{tabular}




\begin{tabular}{|c|c|c|c|c|}
\hline 95 & & \multirow{4}{*}{$\begin{array}{l}\text { 3ページをあけてください。 } \\
\text { San-peeji o akete kudasai. } \\
\text { いってください。 } \\
\text { Itte kudasai. } \\
\text { みてください。 } \\
\text { Mite kudasai. } \\
\text { ペアではなしてください。 } \\
\text { Pea de hanashite kudasai. }\end{array}$} & & \multirow{4}{*}{$\begin{array}{l}\text { Tolong buka halaman } 3 . \\
\text { Tolong ucapkan. } \\
\text { Tolong lihat. } \\
\text { Tolong bicarakan dengan } \\
\text { pasangan. }\end{array}$} \\
\hline 96 & & & & \\
\hline 97 & & & & \\
\hline 98 & & & & \\
\hline 99 & & $\begin{array}{l}\text { もういちどおねがいします。 } \\
\text { Moo ichido onegaishimasu. }\end{array}$ & $\mathrm{L} 2 / 27$ & \\
\hline 100 & & $\begin{array}{l}\text { もうすこしゆっくりいってください。 } \\
\text { Mou sukoshi yukkuri itte kudasai. }\end{array}$ & & \\
\hline 101 & & $\begin{array}{l}\text { はい、おねがいします。 } \\
\text { Hai, onegaishimasu. }\end{array}$ & $\mathrm{L} 5 / 43$ & Ya, tolong ya \\
\hline 102 & & $\begin{array}{l}\text { はこのなかにおねがいします。 } \\
\text { Hako no naka ni onegaishimasu }\end{array}$ & $\mathrm{L} 7 / 56$ & Tolong (letakkan) di dalam kotak \\
\hline 103 & \multirow{2}{*}{$\begin{array}{l}\text { Meminta } \\
\text { perhatian }\end{array}$} & $\begin{array}{l}\text { すみません。 } \\
\text { Sumimasen. }\end{array}$ & $\mathrm{L} 1 / 23$ & Permisi/ maaf. \\
\hline 104 & & $\begin{array}{l}\text { あのう、おなまえは? } \\
\text { Anoo, onamae wa? }\end{array}$ & $\mathrm{L} 3 / 32$ & Permisi, namanya siapa? \\
\hline 105 & \multirow{5}{*}{$\begin{array}{l}\text { Membeli } \\
\text { sesuatu }\end{array}$} & \multirow{5}{*}{$\begin{array}{l}\text { (A) いらっしゃいませ。 } \\
\text { Irasshaimase } \\
\text { (B) すみません。 } \\
\text { Sumimasen } \\
\text { ハンバーガー、ひとつください。 } \\
\text { Hanbaagaa, hitotsu kudasai } \\
\text { (A) はい、ハンバーガーひとつですね。 } \\
\text { Hai, hanbaagaa hitotsu desu ne } \\
\text { どうもありがとうございます。 } \\
\text { Doomo arigatoo gozaimasu }\end{array}$} & \multirow[t]{5}{*}{ L6/49 } & \\
\hline 106 & & & & (B) Permisi \\
\hline 107 & & & & Tolong hamburger satu \\
\hline 108 & & & & (A) Baik, hamburger satu ya \\
\hline 109 & & & & \\
\hline 110 & \multirow{3}{*}{ Bertamu } & \multirow{3}{*}{$\begin{array}{l}\text { (A) いらっしやい。 } \\
\text { Irasshai } \\
\text { (A) どうぞあがってください。 } \\
\text { Doozo agatte kudasai } \\
\text { (B) おじゃまします。 } \\
\text { Ojamashimasu }\end{array}$} & \multirow[t]{3}{*}{$\mathrm{L} 8 / 37$} & (A) Selamat datang. \\
\hline 111 & & & & (A) Silakan masuk. \\
\hline 112 & & & & (B) Permisi. \\
\hline 113 & Menelepon & $\begin{array}{l}\text { もしもし。 } \\
\text { Moshi-moshi }\end{array}$ & $\mathrm{L} 10 / 68$ & Halo. \\
\hline 114 & \multirow{4}{*}{$\begin{array}{l}\text { Memberi } \\
\text { selamat }\end{array}$} & $\begin{array}{l}\text { おめでとう！ } \\
\text { Omedetoo! }\end{array}$ & $\mathrm{L} 10 / 69$ & Selamat! \\
\hline 115 & & $\begin{array}{l}\text { おたんじょうびおめでとう！ } \\
\text { Otanjoobi omedetoo! }\end{array}$ & $\mathrm{L} 10 / 69$ & Selamat ulang tahun! \\
\hline 116 & & $\begin{array}{l}\text { かんぱい! } \\
\text { Kanpai! }\end{array}$ & $\mathrm{L} 10 / 69$ & Bersulang! \\
\hline 117 & & $\begin{array}{l}\text { ありがとう！ } \\
\text { Arigatoo! }\end{array}$ & L10/69 & (B) Terima kasih! \\
\hline 118 & \multirow{3}{*}{$\begin{array}{l}\text { Meminta } \\
\text { maaf }\end{array}$} & $\begin{array}{l}\text { (A) すみませ } ん \text { 。 } \\
\text { Sumimasen. }\end{array}$ & $\mathrm{L} 1 / 23$ & (A) Maaf. \\
\hline 119 & & $\begin{array}{l}\text { (B) いいえ。 } \\
\text { Iie. }\end{array}$ & & (B) Tidak apa-apa. \\
\hline 120 & & すみません。おくれます。 & $\mathrm{L} 2 / 27$ & Maaf, saya terlambat. \\
\hline
\end{tabular}


Sumimasen. Okuremasu.

Tabel 4.2 Perbandingan antara Ungkapan dalam Bahasa Jepang dan Bahasa Indonesia

\begin{tabular}{|c|c|c|c|c|}
\hline \multirow[b]{2}{*}{ No. Data } & \multirow{2}{*}{$\begin{array}{c}\text { Ungkapan } \\
\text { (bahasa Jepang) }\end{array}$} & \multicolumn{3}{|c|}{ Tingkat kemiripan } \\
\hline & & Similar relation & Contrast relation & Zero relation \\
\hline 1 & $\begin{array}{l}\text { (A) おはようございます。 } \\
\text { Ohayoo gozaimasu } \\
\text { (B) Ohayoo gozaimasu }\end{array}$ & $\begin{array}{l}\text { Dalam konteks dan makna } \\
\text { yang sama, bahasa } \\
\text { Indonesia juga memiliki } \\
\text { ungkapan serupa. }\end{array}$ & & \\
\hline 2 & $\begin{array}{l}\text { (A) こんにちは。 } \\
\text { Konnichiwa. } \\
\text { (B) Konnichiwa. }\end{array}$ & Idem. & & \\
\hline 3 & $\begin{array}{l}\text { (A) こんばんは。 } \\
\text { Konbanwa. } \\
\text { (B) Konbanwa }\end{array}$ & Idem. & & \\
\hline 4 & \multirow{2}{*}{$\begin{array}{c}\text { (A) さようなら。 } \\
\text { Sayoonara. } \\
\text { (B) じゃ、また。 } \\
\text { Jaa, mata. }\end{array}$} & Idem. & & \\
\hline 5 & & Idem. & & \\
\hline 6 & \multirow{2}{*}{$\begin{array}{l}\text { (A) お先に } \\
\text { しつれいします。 } \\
\text { Osaki ni shitsurei } \\
\text { shimasu. } \\
\\
\\
\text { (B) お疲れさまでした。 } \\
\text { Otsukaresama deshita. }\end{array}$} & & $\begin{array}{l}\text { Dalam konteks yang sama, } \\
\text { bahasa Indonesia juga memiliki } \\
\text { ungkapan yang kurang lebih } \\
\text { mengandung makna dan tujuan } \\
\text { yang sama: minta izin untuk } \\
\text { mendahului meninggalkan } \\
\text { lokasi. Selain itu, dalam bahasa } \\
\text { Jepang, ungkapan ini } \\
\text { digunakan di situasi } \\
\text { formal/sopan; misal: kantor, } \\
\text { lokasi kerja, dll., tidak seperti } \\
\text { dalam bahasa Indonesia yang } \\
\text { cenderung digunakan dalam } \\
\text { konteks yang lebih santai. }\end{array}$ & \\
\hline 7 & & & $\begin{array}{l}\text { Dalam bahasa Indonesia, } \\
\text { ungkapan perpisahan dengan } \\
\text { ucapan terima kasih seperti ini } \\
\text { tidak memiliki bentuk tetap } \\
\text { seperti pada bahasa Jepang dan } \\
\text { cenderung sangat subjektif, } \\
\text { tergantung dari situasi/kegiatan } \\
\text { yang dibicarakan. }\end{array}$ & \\
\hline 8 & \multirow{2}{*}{$\begin{array}{c}\text { (A) (1) ありがとう } \\
\text { ございます。 } \\
\text { Arigatou gozaimasu. } \\
\\
\text { (2) すみません。 } \\
\text { Sumimasen. }\end{array}$} & Idem. & & \\
\hline 9 & & & $\begin{array}{l}\text { Orang Jepang juga berterima } \\
\text { kasih dengan menggunakan } \\
\text { kata maaf. Biasanya ucapan ini } \\
\text { digunakan karena orang yang }\end{array}$ & \\
\hline
\end{tabular}




\begin{tabular}{|c|c|c|c|c|}
\hline & & & $\begin{array}{l}\text { dibantu tersebut merasa telah } \\
\text { menyusahkan orang yang } \\
\text { membantu. }\end{array}$ & \\
\hline 10 & $\begin{array}{c}\text { (B) } い い え ~ \\
\text { Iie }\end{array}$ & & $\begin{array}{l}\text { Makna ungkapan ini mirip } \\
\text { dengan "tidak apa-apa" dalam } \\
\text { bahasa Indonesia.Hal ini masih } \\
\text { berkaitan dengan pola pikir } \\
\text { orang Jepang seperti di atas. }\end{array}$ & \\
\hline 11 & $\begin{array}{l}\text { はじめまして。山田です。 } \\
\text { Hajimemashite. } \\
\text { Yamada desu. }\end{array}$ & Idem. & & \\
\hline 12 & \multirow{3}{*}{$\begin{array}{l}\text { (A) おなまえは? } \\
\text { O-namae wa? } \\
\text { (B) ワンです。 } \\
\text { Wan desu. } \\
\text { (B) どうぞよろしく。 } \\
\text { Doozo yoroshiku. } \\
\\
\text { (A) どうぞよろしく。 } \\
\text { Doozo yoroshiku. }\end{array}$} & Idem. & & \\
\hline 13 & & Idem. & & \\
\hline 14 & & & $\begin{array}{l}\text { Dalam bahasa Indonesia, } \\
\text { ungkapan semacam ini tidak } \\
\text { memiliki bentuk tetap seperti } \\
\text { pada bahasa Jepang dan } \\
\text { cenderung lebih bebas, } \\
\text { tergantung dari situasi/kegiatan } \\
\text { yang dibicarakan. }\end{array}$ & \\
\hline 15 & \multirow{4}{*}{$\begin{array}{l}\text { (A) はじめまして。 キムです。 } \\
\text { Hajimemashite. Kimu } \\
\text { desu. } \\
\text { どうぞよろしく。 } \\
\text { Doozo yoroshiku. } \\
\text { (B) はじめまして。野田です。 } \\
\text { Hajimemashite. Noda } \\
\text { desu. } \\
\text { どうぞよろしく。 } \\
\text { Doozo yoroshiku. }\end{array}$} & Idem. & & \\
\hline 16 & & & Idem. & \\
\hline 17 & & Idem & & \\
\hline 18 & & & Idem & \\
\hline 19 & \multirow{2}{*}{$\begin{array}{l}\text { はじめまして。 } \\
\text { 佐藤と 申します。 } \\
\text { Hajimemashite. } \\
\text { Satoo to mooshimasu. } \\
\text { どうぞよろしく お願いします。 } \\
\text { Doozo yoroshiku } \\
\quad \text { onegaishimasu }\end{array}$} & & $\begin{array}{l}\text { Bahasa Jepang memiliki } \\
\text { berbagai tingkat bahasa, } \\
\text { termasuk pula dalam } \\
\text { memperkenalkan diri. } \\
\text { Ungkapan ini digunakan dalam } \\
\text { situasi formal. }\end{array}$ & \\
\hline 20 & & & Idem. & \\
\hline 21 & $\begin{array}{l}\text { いただきます。 } \\
\text { Itadakimasu }\end{array}$ & & & $\begin{array}{l}\text { Bahasa Indonesia sama } \\
\text { sekali tidak memiliki } \\
\text { ungkapan seperti ini. } \\
\text { Ungkapan ini sering kali } \\
\text { diterjemahkan menjadi } \\
\text { "selamat makan". Akan } \\
\text { tetapi, terjemahan } \\
\text { tersebut dalam } \\
\text { masyarakat Indonesia } \\
\text { tidak betul-betul } \\
\text { digunakan. Pada } \\
\text { dasarnya, "itadakimasu" } \\
\text { digunakan sebagai } \\
\text { ungkapan terima kasih } \\
\text { kepada siapapun yang } \\
\text { telah membuat atas } \\
\text { makanan yang diterima. }\end{array}$ \\
\hline
\end{tabular}




\begin{tabular}{|c|c|c|c|}
\hline 22 & $\begin{array}{l}\text { ごちそうさま。 } \\
\text { Gochisoosama }\end{array}$ & & $\begin{array}{l}\text { Seperti halnya } \\
\text { "itadakimasu", } \\
\text { "gochisoosama" juga } \\
\text { digunakan sebagai } \\
\text { ungkapan terima kasih } \\
\text { atas makanan yang } \\
\text { diterima. Akan tetapi, } \\
\text { "gochisoosama" } \\
\text { diucapkan setelah selesai } \\
\text { makan. Dalam bahasa } \\
\text { Indonesia, tidak ada } \\
\text { ungkapan yang serupa. }\end{array}$ \\
\hline 23 & \multirow{7}{*}{$\begin{array}{l}\text { (A) この人はだれですか。 } \\
\text { Kono hito wa dare desu } \\
\text { ka? } \\
\text { (B) わたしのあにです。 } \\
\text { Watashi no ani desu. } \\
\text { (A) へえ、かっこいいですね。 } \\
\text { おいくつですか。 } \\
\text { Hee, kakkoii desu ne. } \\
\text { Oikutsu desu ka? } \\
\text { (B) 33さいです。 } \\
\text { 33-sai desu. } \\
\text { (A) どこに すんでいますか。 } \\
\text { Doko ni sundeimasu ka? } \\
\text { (B) 東京にすんでいます。 } \\
\text { かいしやいんです。 } \\
\text { Tookyoo ni sundeimasu. } \\
\text { Kaishain desu. } \\
\text { (A) そうですか。 } \\
\text { Soo desu ka. }\end{array}$} & \multirow{7}{*}{$\begin{array}{l}\text { - Dalam percakapan ini, } \\
\text { ungkapan dalam bahasa } \\
\text { Jepang yang digunakan } \\
\text { kurang lebih mirip } \\
\text { dengan bahasa } \\
\text { Indonesia. Sebagian } \\
\text { besar kalimat yang } \\
\text { digunakan bukan } \\
\text { kalimat utuh dan } \\
\text { cenderung dibuat } \\
\text { seringkas mungkin. } \\
\\
\text { - Dalam memberi pujian, } \\
\text { bentuk kalimat } \\
\text { 'mengkonfirmasi' } \\
\text { sama-sama dipakai } \\
\text { dalam kedua bahasa. }\end{array}$} & \\
\hline 24 & & & \\
\hline 25 & & & \\
\hline 26 & & & \\
\hline 27 & & & \\
\hline 28 & & & \\
\hline 29 & & & \\
\hline 30 & \multirow{5}{*}{$\begin{array}{l}\text { (A) この子はだれですか。 } \\
\text { Kono ko wa dare desu } \\
\text { ka? } \\
\text { (B) ああ、あにのこどもです。 } \\
\text { Aa, ani no kodomo desu. } \\
\text { (A) かわいいですね。 } \\
\text { おいつですか。 } \\
\text { Kawaii desu ne. Oikutsu } \\
\text { desu ka? } \\
\text { (B) 6さいです。 } \\
\text { 6-sai desu. } \\
\text { (A)6さい。そうですか。 } \\
\text { 6-sai. Soo desu ka. }\end{array}$} & \multirow{5}{*}{$\begin{array}{l}\text { Dalam konteks dan makna } \\
\text { yang sama, bahasa } \\
\text { Indonesia juga memiliki } \\
\text { ungkapan serupa. }\end{array}$} & \\
\hline 31 & & & \\
\hline 32 & & & \\
\hline 33 & & & \\
\hline 34 & & & \\
\hline 35 & \multirow{4}{*}{$\begin{array}{l}\text { (A) このひとは だれですか。 } \\
\text { Kono hito wa dare desu } \\
\text { ka? } \\
\text { (B) ちちです。 } \\
\text { Chichi desu. } \\
\text { (A) え、おとうさんは } \\
65 \text { さいです。 } \\
\text { E, otoosan. Oikutsu desu } \\
\text { ka? } \\
\text { (B) ええっと、ちちは } \\
65 \text { さいです。 } \\
\text { Eetto, chichi wa } 65 \text {-sai }\end{array}$} & \multirow{4}{*}{ Idem. } & \\
\hline 36 & & & \\
\hline 37 & & & \\
\hline 38 & & & \\
\hline
\end{tabular}




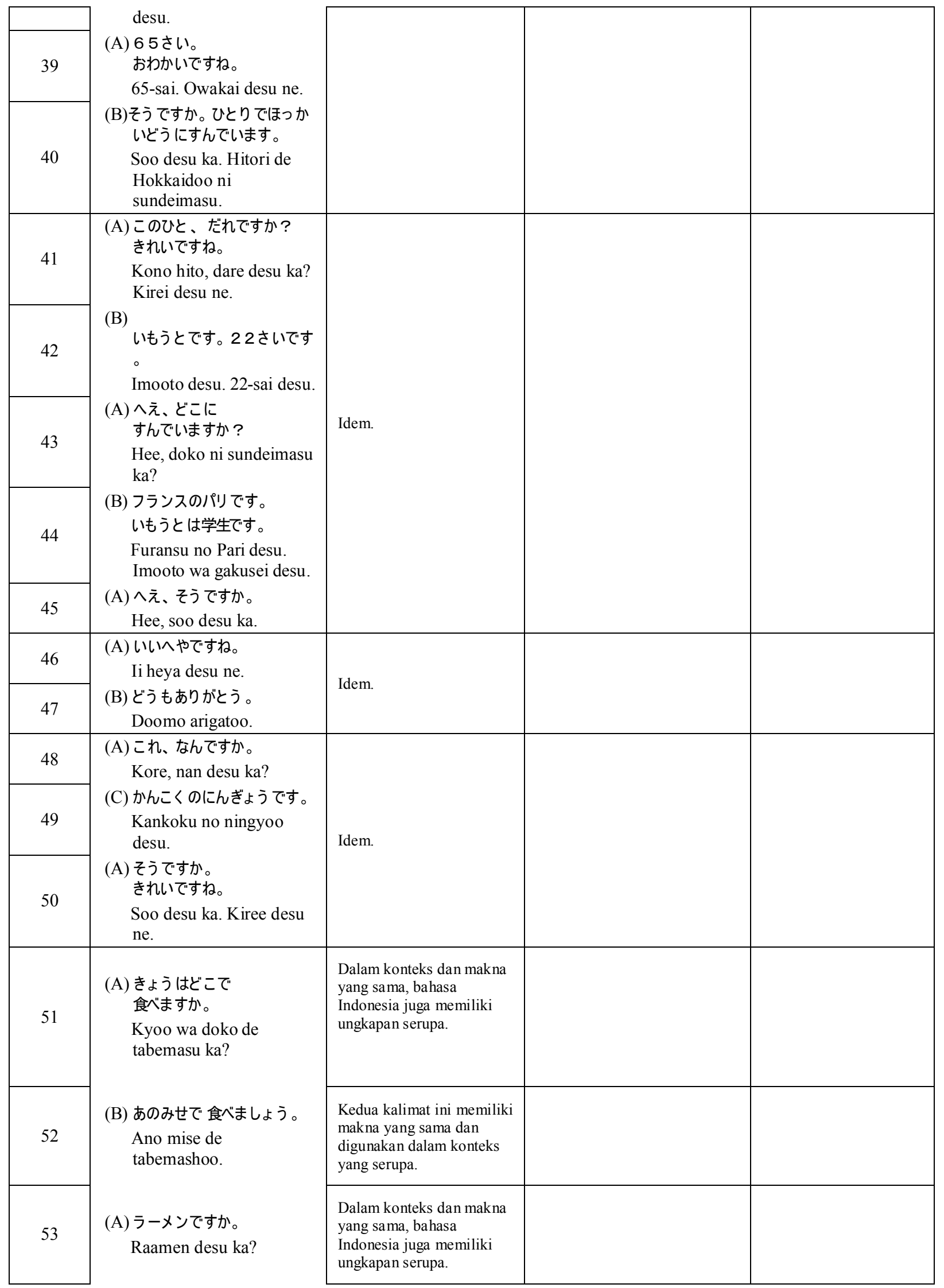




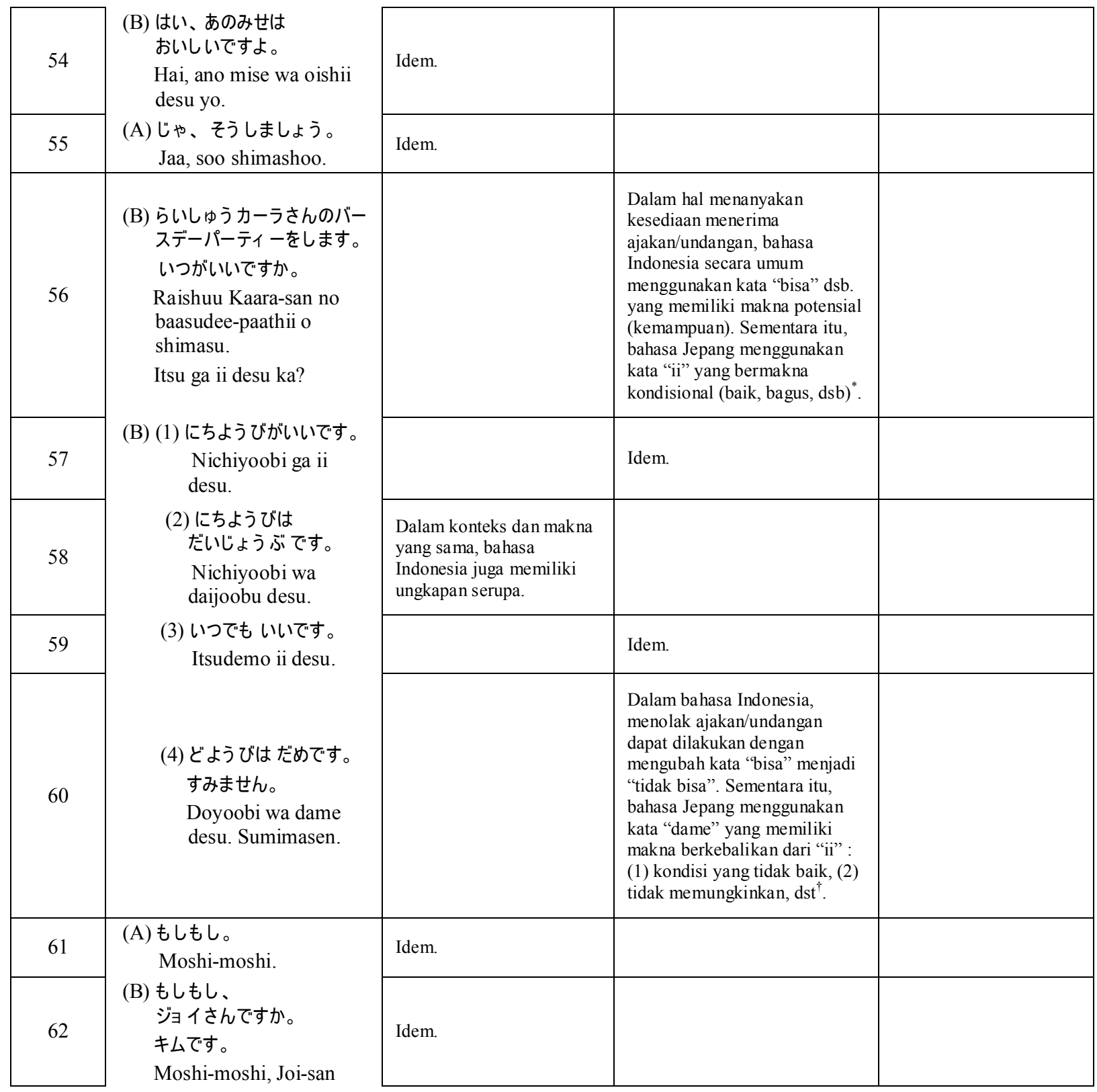

\footnotetext{
*よ・い【良い/善い $\nabla^{*}$ 如 $/ \nabla$ 吉い $/ \nabla$ 僥い】
}

[ 形 [ 文 $]$ よ・し[ク]

1（多「良い」「好い」と書人）人の行動·性質や事物の状態な゙゙が水準を超えているさま。

Disandur dari http://dictionary.goo.ne.jp/leaf/jn2/226039/m0u/良W/ 1 Oktober 2015, pukul 19.46 WIB

†だめ【駄目】

名・形動] 《5が原義》

1

よくない状態にあること。また、用をなさない状態にあること。また、そのさま。「暑さで食べ物が一になる」「

重病で、もう一らしい」「一なやつ」

2 効果がないこと。また、そのさま。むだ。「いくら頼んでも一だ」「一でもともと」

3 しようとしてもできないこと。また、そのさま。不可能。「これ以上歩けと言われてもとても一だ」

Disandur dari http://dictionary.goo.ne.jp/leaf/jn2/226039/m0u/駄目/ pada tanggal 1 Oktober 2015, pukul $20.32 \mathrm{WIB}$ 


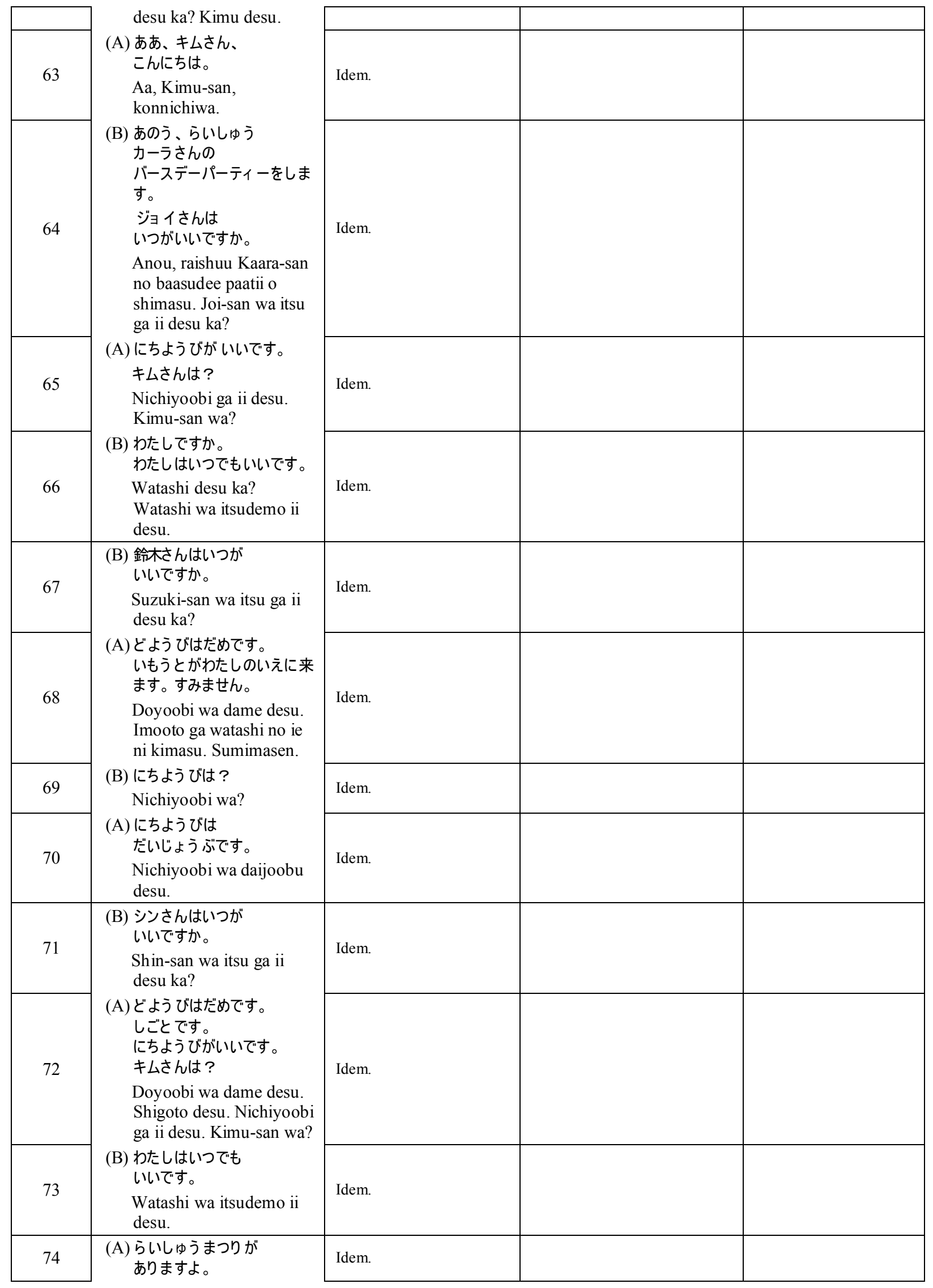




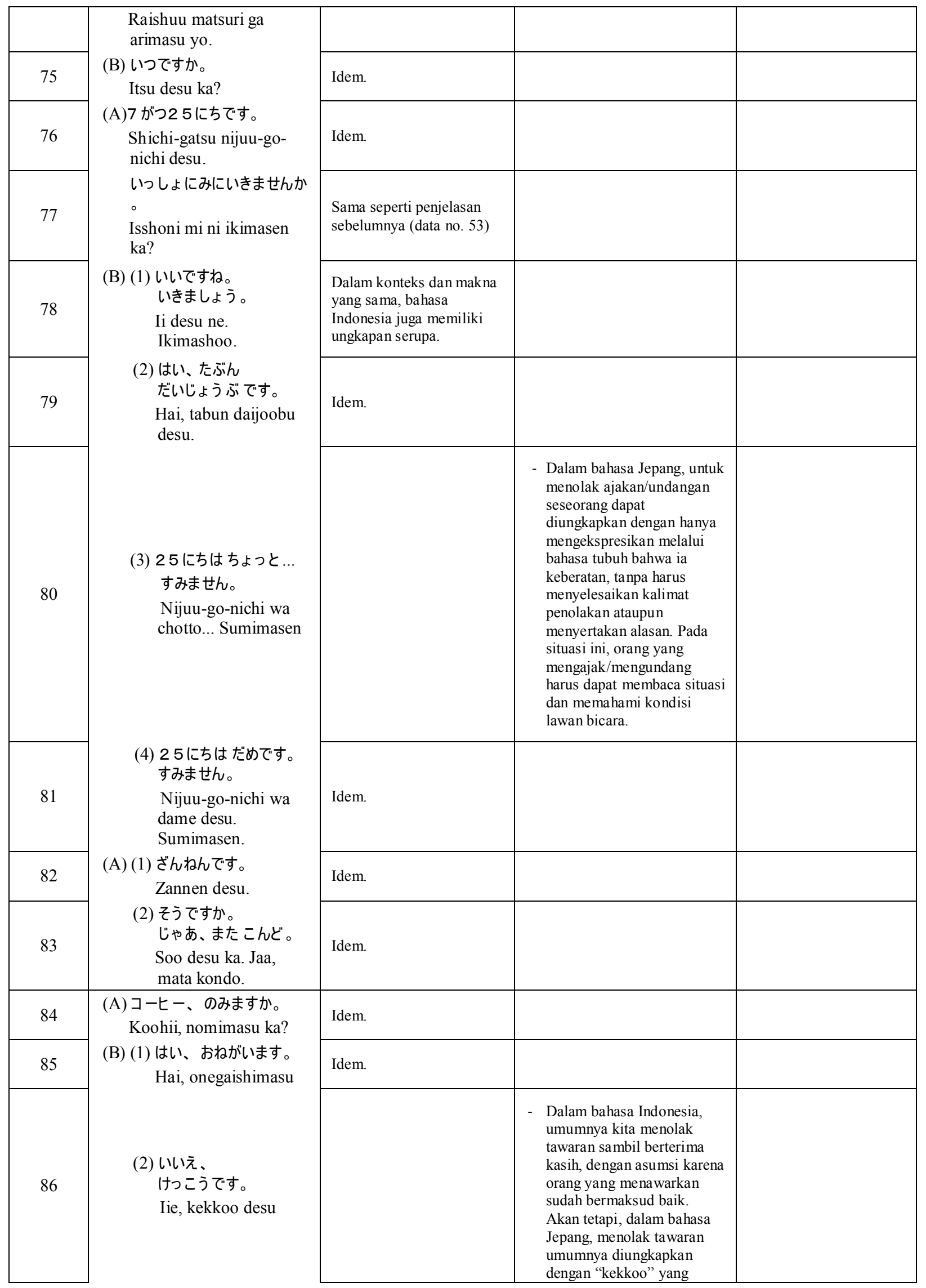




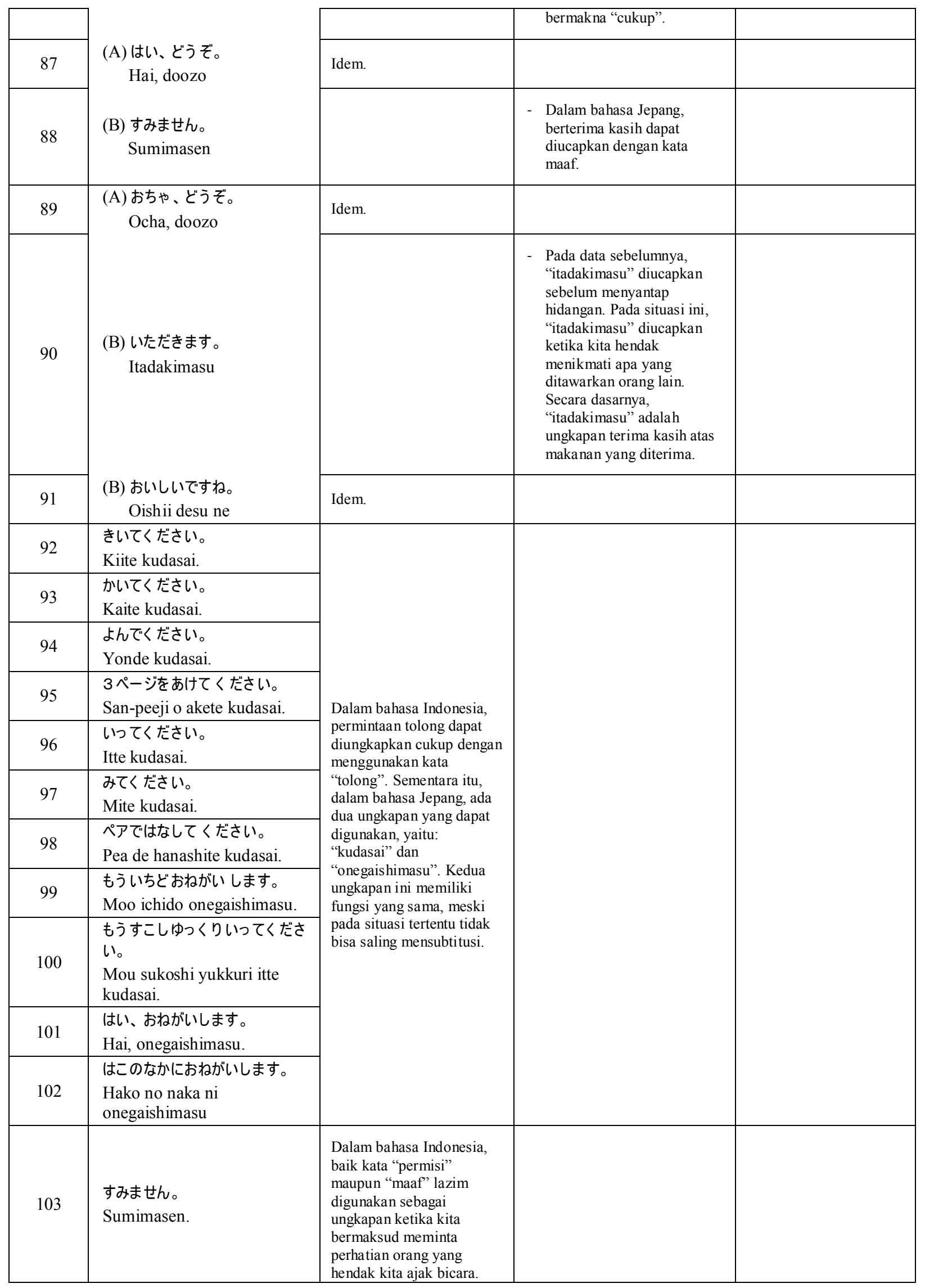




\begin{tabular}{|c|c|c|c|c|}
\hline & & $\begin{array}{l}\text { Begitu pula dalam bahasa } \\
\text { Jepang, "sumimasen" } \\
\text { memiliki makna dan fungsi } \\
\text { bahasa yang serupa. }\end{array}$ & & \\
\hline 104 & $\begin{array}{l}\text { あのう、おなまえは? } \\
\text { Anoo, onamae wa? }\end{array}$ & $\begin{array}{l}\text { Dalam konteks dan makna } \\
\text { yang sama, bahasa } \\
\text { Indonesia juga memiliki } \\
\text { ungkapan serupa. }\end{array}$ & & \\
\hline 105 & \multirow{5}{*}{$\begin{array}{l}\text { (A) いらっしゃいませ。 } \\
\text { Irasshaimase } \\
\text { (B) すみません。 } \\
\text { Sumimasen } \\
\text { ハンバーガー、ひとつくださ } \\
\text { い。 } \\
\text { Hanbaagaa, hitotsu } \\
\text { kudasai } \\
\text { (A) } \\
\text { はい、ハンバーガーひとつで } \\
\text { すね。 } \\
\text { Hai, hanbaagaa hitotsu } \\
\text { desu ne } \\
\text { どうもありがとうございます } \\
\text { 。 } \\
\text { Doomo arigatoo } \\
\text { gozaimasu }\end{array}$} & Idem. & & \\
\hline 106 & & $\begin{array}{l}\text { Sama seperti penjelasan } \\
\text { pada data sebelumnya } \\
\text { (data no. 103) }\end{array}$ & & \\
\hline 107 & & $\begin{array}{l}\text { Dalam konteks dan makna } \\
\text { yang sama, bahasa } \\
\text { Indonesia juga memiliki } \\
\text { ungkapan serupa. }\end{array}$ & & \\
\hline 108 & & Idem. & & \\
\hline 109 & & Idem. & & \\
\hline 110 & $\begin{array}{l}\text { (A) いらっしやい。 } \\
\text { Irasshai }\end{array}$ & & $\begin{array}{l}\text { Dalam bahasa Indonesia, } \\
\text { kita tidak benar-benar } \\
\text { mengucapkan "selamat } \\
\text { datang" pada orang yang } \\
\text { sedang berkunjung ke } \\
\text { rumah. Kita cukup dengan } \\
\text { mengatakan "silakan } \\
\text { masuk". } \\
\\
\text { - Ketika bertamu, "selamat } \\
\text { datang" dalam bahasa } \\
\text { Jepang memiliki sedikit } \\
\text { perbedaan dengan yang } \\
\text { diucapkan di tempat } \\
\text { umum/toko. }\end{array}$ & \\
\hline 111 & $\begin{array}{c}\text { (A) どうぞあがってください。 } \\
\text { Doozo agatte kudasai }\end{array}$ & & $\begin{array}{l}\text { - "silakan masuk" yang } \\
\text { digunakan untuk } \\
\text { mempersilakan tamu masuk } \\
\text { dalam bahasa Jepang, } \\
\text { memiliki ungkapan sendiri: } \\
\text { "doozo agatte kudasai". } \\
\text { Ungkapan ini dapat } \\
\text { diartikan secara harafiah } \\
\text { sebagai "silakan naik". } \\
\text { Ungkapan ini terbentuk } \\
\text { karena rumah-rumah di } \\
\text { Jepang selalu memiliki } \\
\text { 'genkan', yaitu lantai yang } \\
\text { lebih tinggi pada pintu } \\
\text { masuk. }\end{array}$ & \\
\hline 112 & $\begin{array}{r}\text { (B) おじゃします。 } \\
\text { Ojamashimasu } \\
\end{array}$ & & $\begin{array}{l}\text { - "permisi" dalam bahasa } \\
\text { Indonesia digunakan tidak }\end{array}$ & \\
\hline
\end{tabular}




\begin{tabular}{|c|c|c|c|}
\hline & & & $\begin{array}{l}\text { hanya dalam situasi ketika } \\
\text { kita hendak minta izin } \\
\text { membuka pembicaraan, } \\
\text { menyela ataupun } \\
\text { semacamnya. Tetapi juga } \\
\text { dapat digunakan untuk } \\
\text { minta izin masuk ke tempat } \\
\text { milik orang lain. } \\
\\
\text { - Sementara itu, } \\
\text { "ojamashimasu" digunakan } \\
\text { hanya ketika kita minta izin } \\
\text { masuk ke tempat milik } \\
\text { orang lain. }\end{array}$ \\
\hline 113 & $\begin{array}{l}\text { もしもし。 } \\
\text { Moshi-moshi }\end{array}$ & Idem. & \\
\hline 114 & $\begin{array}{l}\text { おめでとう！ } \\
\text { Omedetoo! }\end{array}$ & Idem. & \\
\hline 115 & $\begin{array}{l}\text { おたんじょうびおめでとう！ } \\
\text { Otanjoobi omedetoo! }\end{array}$ & Idem. & \\
\hline 116 & $\begin{array}{l}\text { かんぱい! } \\
\text { Kanpai! }\end{array}$ & & $\begin{array}{l}\text { Pada umumnya, di Indonesia } \\
\text { tidak ada budaya minum- } \\
\text { minum bersama seperti di } \\
\text { Jepang, sehingga ungkapan } \\
\text { "bersulang" tidak terlalu lazim } \\
\text { digunakan meskipun memang } \\
\text { kita memiliki ungkapan } \\
\text { tersebut. }\end{array}$ \\
\hline 117 & $\begin{array}{l}\text { ありがとう！ } \\
\text { Arigatoo! }\end{array}$ & $\begin{array}{l}\text { Dalam konteks dan makna } \\
\text { yang sama, bahasa } \\
\text { Indonesia juga memiliki } \\
\text { ungkapan serupa. }\end{array}$ & \\
\hline 118 & $\begin{array}{l}\text { (A) すみません。 } \\
\text { Sumimasen. }\end{array}$ & Idem. & \\
\hline 119 & $\begin{array}{l}\text { (B) いいえ。 } \\
\text { Iie. }\end{array}$ & Idem. & \\
\hline 120 & $\begin{array}{l}\text { すみません。 } \\
\text { おくれます。 } \\
\text { Sumimasen. Okuremasu. }\end{array}$ & Idem. & \\
\hline
\end{tabular}

Dari analisis ini, dapat kita simpulkan bahwa buku Marugoto jilid katsudou A1 memang sangat sesuai digunakan untuk mengajarkan pembelajar pemula. Dalam buku ini, dipilih ungkapan-ungkapan sederhana yang tidak memberatkan pembelajar untuk memahami bahasa Jepang. Bagi para pengajar, terdapat sejumlah poin yang harus lebih diperhatikan dalam mengajarkan ungkapan, terutama pada ungkapan dalam kategori contrast relation dan zero relation.

Pada kategori contrast relation, ungkapan dari kedua bahasa memiliki perbedaan yang cukup mencolok. Sehingga pembelajar yang sedang berusaha 
memahami ungkapan tersebut akan cenderung menitikberatkan 'perbedaan' yang terdapat dari ungkapan pada kedua bahasa. Dalam hal ini, pengajar harus mampu menguraikan sedemikian rupa perbedaan yang dimaksud dari setiap ungkapan yang akan diajarkan; apakah pebedaan itu pada situasi penggunaan, cara menyampaikan, maupun maknanya.

Sementara itu, kategori zero relation berarti pada bahasa pembelajar (dalam hal ini Bahasa Indonesia) tidak memiliki ungkapan sejenis sebagai pembanding. Ungkapan yang termasuk kategori ini membutuhkan gambaran situasi untuk menjelaskan fungsi bahasanya. Gambaran situasi dapat dijelaskan dengan bantuan media visual seperti gambar, foto, ataupun video.

Berdasarkan data di atas, 97 data dari 120 data merupakan termasuk dalam similar relation. Data tersebut menunjukkan bahwa ungkapan-ungkapan yang diperkenalkan dalam buku ini sangat sesuai untuk digunakan pembelajar asing, terutama pembelajar Indonesia. Sebagian besar ungkapan dapat dipahami dengan mudah oleh pembelajar Indonesia karena situasi dan fungsi bahasa yang mirip dengan ungkapan yang digunakan dalam Bahasa Indonesia.

Selain ungkapan yang mudah dipahami, terdapat sejumlah ungkapan yang memerlukan perhatian lebih dalam pengajaran. Sebanyak 21 data ungkapan dalam bahasa Jepang merupakan ungkapan yang tergolong kategori contrast relation, dan 2 data ungkapan dalam kategori zero relation. 21 data ungkapan kategori contrast relation terdapat pada fungsi bahasa 1) salam perpisahan, 2) berterima kasih, 3) perkenalan, 4) mengungkapkan ajakan/undangan serta menanggapi ajakan/undangan, 5) menawarkan, 6) bertamu, dan 7) memberi selamat. Ungkapan kategori contrast relation yang terdapat pada 1) perpisahan, 2) berterima kasih, 3) perkenalan, dan 7) memberi selamat, tetap harus disampaikan di awal pembelajaran. Ungkapan-ungkapan tersebut merupakan ungkapan dasar dalam berinteraksi dengan orang lain sehingga sebaiknya sudah diajarkan sedini mungkin. Metode pengajaran harus lebih diperhatikan dalam mengajarkan ungkapan-ungkapan ini sehingga pembelajar mampu memahami tanpa mengalami kesalahan pemahaman. Sedangkan, dalam mengajarkan mengenai ungkapan 4) ajakan/undangan dan menanggapi ajakan/undangan, 5) menawarkan, dan 6) bertamu, perlu pertimbangan lebih lanjut. 
Ungkapan tersebut memiliki tingkat kesulitan yang lebih tinggi untuk dipahami pembelajar, sebab ungkapan-ungkapan tersebut erat kaitannya dengan pola pikir, budaya, dan norma masyarakat Jepang dalam berinteraksi dengan sesama. Oleh karena itu, dalam mengajarkan ungkapan-ungkapan tersebut, dibutuhkan media tambahan maupun perluasan ilmu untuk membantu pengajar dalam menjelaskan.

Pada kategori zero relation, ungkapan yang masuk dalam kategori ini terdapat 2 data, yaitu ungkapan yang digunakan 'ketika makan'. Dalam bahasa Jepang, ungkapan “itadakimasu” (いただきます; diucapkan sebelum makan) dan “gochisoosama” (ごちそうさま; diucapkan setelah makan) tidak memiliki ungkapan pembanding dalam bahasa Indonesia. Masyarakat Indonesia secara umum tidak memiliki budaya seperti Jepang: bersama-sama mengucapkan ungkapan terima kasih atas makanan yang diterima baik sebelum maupun sesudah. Dari segi situasi, konteks, bahkan fungsi bahasa maupun budaya, masyarakat Indonesia secara umum tidak memiliki ungkapan yang sejenis. Untuk dapat memahami hal ini, pembelajar perlu dikenalkan gambaran detil mengenai situasi penggunaan ungkapan ini. Menurut pengalaman penulis, pengajaran ungkapan ini lebih mudah ketika diajarkan pada pembelajar yang memang pernah melihat situasi yang dimaksud melalui acaraacara televisi dari Jepang.

\section{Kesimpulan dan Saran}

Perbedaan pola pikir, budaya, dan norma tak jarang ditemui dalam mempelajari bahasa. Oleh karena itu, sangat penting bagi pengajar untuk mengenalkan situasi dan konteks penggunaan ungkapan pada pembelajar sehingga mereka dapat memahami fungsi dan penggunaannya secara tepat. Seperti yang ditunjukkan pada pembahasan di atas, ungkapan bahasa Jepang pun tidak lepas dari pola pikir, budaya, dan norma masyarakat Jepang. Beberapa ungkapan dari buku ajar Marugoto A1 jilid katsudou yang dimaksud, yaitu: ungkapan ajakan/undangan dan menanggapi ajakan/undangan, menawarkan, dan bertamu, serta ungkapan yang tidak ada ungkapan pembanding dari Bahasa Indonesia seperti ungkapan “itadakimasu”-"gochisoosama”. Maka dari itu, dalam pengajaran ungkapan ada halhal yang perlu perhatian lebih lanjut. Selain diperlukan gambaran situasi terkait 
penggunaan ungkapan yang diajarkan, penjelasan mengenai pola pikir serta norma di masyarakat Jepang juga diperlukan untuk membantu ketepatan pemahaman pembelajar sehingga hal ini menuntut perluasan pengetahuan dari pengajar.

Pengenalan pola pikir maupun norma dan budaya masyarakat Jepang dapat dirancang secara bertahap sepanjang termin pembelajaran. Oleh karenanya, dalam sequence penempatan urutan materi, ungkapan di atas dapat diletakkan di bagian mengenah akhir pengajaran dengan asumsi bahwa pembelajar telah cukup mengenal sedikit banyak pola pikir, norma, maupun budaya masyarakat Jepang. Akan tetapi, pengalihan materi seperti ini sesekali sulit dilakukan oleh karena fakta bahwa ungkapan-ungkapan tersebut sangat sering digunakan masyarakat Jepang sehingga urgensi pemahaman terhadap ungkapan tersebut pun meningkat. Pengajaran terhadap ungkapan ini dapat dilakukan lebih efisien dengan bantuan media tambahan seperti gambar, video, atau bahkan mungkin komik maupun permainan terkait ungkapan yang diajarkan. Media tambahan yang menarik akan lebih memacu ketertarikan pembelajar sehingga mempermudah proses penyampaian informasi.

\section{Daftar Pustaka}

Geethakumary, V. (2002). A Contrastive Analysis of Hindi and Malayalam, $\mathrm{PhD}$ Dissertation, Language in India, Vol. 2 (Diunduh dari http://repository.um.edu.my/16277/1/LANGUAGE\%20IN\%20INDIA.pdf 25 September 2015)

Jacobs, G. M., \& Ratmanida. (1996). Intergrating language functions and collaborative skills in the second language classroom. TESL Reporter, 29, 1: 21-33 (diunduh dari https://ojs.lib.byu.edu/spc/index.php/TESL/article/viewFile/3586/3360 pada tanggal 27 September 2015)

Kinsella, K. (2010). Academic Language Function Toolkit. (diunduh dari http://www.htsb.org/wp-content/uploads/2014/07/Academic-Language-Functions-toolkit.pdf pada tanggal 27 September 2015)

Pallotti, G. (2010). Doing interlanguage analysis in school contexts. "Communicative proficiency and linguistic development : intersections between SLA and language testing research". Vol. 1, halaman 159-190. (Diunduh dari http://eurosla.org/monographs/EM01/159-190Pallotti.pdf pada tanggal 25 September 2015) 
Ringbom, H. (2007). Cross-linguistic similarity in foreign language learning. Clevedon England: Multilingual Matters.

The Japan Foundation. (2013). Marugoto Starter Al Katsudoo: Coursebook for communicative language activities. Tokyo: Sanshusha Publishing.

Y. Abe, T. Suzuki, B. Liang, T. Utsuro, M. Yamamoto, S. Matsuyoshi, Y. Kawada. (2011). Example-based translation of Japanese functional expressions utilizing semantic equivalence classes. In Proc. MT Summit XIII 4th Workshop on Patent Translation, halaman 91-103. (Diunduh dari http://nlp.iit.tsukuba.ac.jp/papers/utsuro/MTSummitXIII_Proceedings_Final-2011-abe-fromproc.pdf pada tanggal 21 September 2015)

Yuwono, S. E., (2010). Contrastive Analysis of English and Indonesian Noun Phrase. (diunduh dari http://download.portalgaruda.org/article.php? article $=253330$ $\&$ val $=6820 \&$ title $=$ CONTRASTIVE\%20ANALYSIS $\% 200 F \% 20$ ENGLISH $\% 20$ AND\%20I NDONESIAN\%20NOUN\%20PHRASE pada tanggal 21 September 2015) 